\title{
Grænsezoner og transportkorridorer i Slesvig
}

\author{
Af Mette PilgaArd
}

I artiklen redegør Mette Pilgaard for samspillet mellem de forbindelseslinjer og de barrierer, som fandtes i Jylland fra tidlig romersk jernalder til cirka år 1200. Heri indgik befæstningsanlæg som Danevirke, borge og volde som Olgerdiget og $Æ$ Vold. Men ikke kun disse menneskeskabte forhindringer gav de tidlige magthavere mulighed for økonomisk og politisk kontrol. Også store skovområder kan have indgået i forsvars- og kontrolsystemet. Artiklen er baseret på forfatterens speciale, som blev udarbejdet som led i kandidatuddannelsen i forhistorisk arkæologi ved Institut for Antropologi, Arkæologi og Lingvistik, Århus Universitet.

\section{Indledning}

Grænsezoner i form af store skove og andre former for ødeområder er velkendte fænomener i Nordeuropa fra før Kristi fødsel og langt op i middelalderen. Har disse områder været uovervindelige naturgivne barrierer, sikkerhedsmæssige barrierer, kulturelle og politiske grænser eller en del af den daglige økonomi - eller måske en kombination af flere af disse faktorer?

Transportkorridorer til vands og lands har været afgørende for vareudveksling, tilførsel af råvarer, forsvar og transport af lokal produktion. Effektiv kontrol med færdslen har været en vigtig forudsætning for styring af samfundet.

Slesvig har en række meget interessante, forhistoriske transportkorridorer som Hærvejen, landbaserede spærrings- og kontrolanlæg som Olgerdiget, $Æ$ Vold, Danevirke og voldsteder/borge. Artiklen præsenterer disse anlæg, og der spørges om deres funktion og samspil med grænsezonerne fra tiden omkring Kristi fødsel til ca. $1200 \mathrm{i}$ middelalderen.

\section{Grænsezoners funktion}

Allerede antikke forfattere som Cæsar og Tacitus beretter, at Germanien havde meget store skove og sumpe, som adskilte de enkelte, ger- 
manske bosætningsområder. Grænsezoner i form af store skove, sumpområder og i øvrigt ødeområder, som adskilte stammer og bosætningsområder, var kendetegnende for Nordeuropa langt op i middelalderen. Dette udgjorde et stort problem for romerne - den velorganiserede romerske hær blev således $\mathrm{i}$ år ni slået af germanerne ved Teutoburger Wald, da den forsøgte at erobre området mellem Rhinen og Elben. En af grundene til den mislykkede romerske erobring er at finde i den germanske geografi, natur og samfund. Den romerske hær var vant til at marchere ad gode veje, men blev mødt af tætte skove uden egentlige veje og havde derfor store problemer med at komme frem $^{1}$. Transportkorridorer har altid - også i de germanske samfund været et bærende element $i$ et samfunds muligheder for kommunikation.

En effektiv samfærdsel både til lands og vands har været afgørende for vareudveksling, tilførsel af råvarer, forsvar og transport af lokal produktion. Effektiv kontrol med færdslen i transportkorridorer har været en særdeles central og vigtig forudsætning for styring af samfundet. I Danmark er de skriftlige kilder næsten tavse til engang i vikingetiden, men arkæologien anvender foruden arkæologiske fund og tolkningen heraf brug af en række hjælpediscipliner som naturvidenskabelige metoder og stednavne. Ved tolkning af arkæologisk materiale får arkæologer også stor inspiration fra bl.a. samfundsvidenskaben, etnografien og antropologien - f.eks. til, hvordan de forhistoriske samfund kunne være opbygget og politisk organiseret. Når der er ligheder i det arkæologiske materiale i Danmark og andre steder i Europa, kan man trække paralleller til udviklingen her.

Et illustrativt eksempel på tolkningsmuligheder er, om der har ligget bevidste intentioner bag grænseskoves og andre ødeområders eksistens. Er de opretholdt for at skabe en grænse, eller er grænsen blot faldet, hvor der i forvejen fandtes et større ubebygget og skovrigt område? Arkæologisk er det ikke muligt at besvare spørgsmålet uden skriftlige kilder, der beskæftiger sig med dette. Svaret må også ses i sammenhæng med den funktion, som disse områder har haft. Arkæologisk og med den viden, som haves om den økonomiske, sociale og politiske udvikling især fra 600 til 1200 i Slesvig, har grænsezoner i form af eksisterende store skovområder og ubeboede områder været brugt bevidst, hvor de har opfyldt en ønsket funktion - ofte sammen med andre naturgivne barrierer, men der er ikke belæg for at sige, at de er opretholdt for at skabe en grænse. 
Store, ubeboede ødeområder som store skove, sumpe, moser og andre former for ugæstfrie områder er kendte fænomener i Nordeuropa fra i hvert fald omkring Kristi fødsel og langt op i middelalderen. Sådanne områder findes bl.a. i England, i det slaviske område i Østeuropa, i Tyskland og i Skåne. Sådanne områder må betegnes som grænsezoner, som adskiller beboede områder. Grænseområder er interessante og dynamiske, da de på den ene side adskiller - f.eks. som bufferzoner, der hindrer konflikt - og på den anden side samler som zoner for kontakt og udveksling af gods, ideer og religion ${ }^{2}$.

I denne sammenhæng er begrebet "grænse« interessant, idet det rummer mange betydninger. En grænse kan afgrænse noget tidsmæssigt, kulturelt, politisk, territorielt eller naturbestemt f.eks. i form af træer, skove, vand m.v. Når vi i dag passerer den dansk-tyske grænse, forstår vi ved grænsen en »lineær grænse«, der er en klar afgrænsning mellem to områder som f.eks. politisk fastlagte grænser. Men grænser i lineær form har ikke haft en større udbredelse før et stykke op i middelalderen. Mange grænser har netop været grænseområder mere eller mindre ubeboede områder - ofte skov- og vådområder, som var omgivet af beboede områder. Det urgermanske ord for grænse og grænseområde var "marka«, som også har relation til det latinske "margo" og "margonis« - betydende kant/hjørne/udkant. En grænse/»marka « kunne således både være en lineær grænse eller et grænseområde. Grænseområder har ikke nødvendigvis haft en fast afgrænsning, men har været en flydende størrelse. Romerrigets Limes-grænse var således et grænseområde - ikke en lineær grænse, hvor der var forskellige former for kontakt og magtanvendelse mellem romerne og germanerne ${ }^{3}$.

I forhistorisk tid uden skriftlige kilder er grænser svære at påvise, men arkæologien arbejder med såkaldte kultur- eller lokalgrupper, som er kendetegnet ved inden for et geografisk område at have haft et ensartet arkæologisk genstandsmateriale. Der kan være en vis variation i udbredelsen af forskelligt kildemateriale, og kultur-/lokalgrupper kan overlappe. Det skal understreges, at en kulturgruppe ikke på nogen måde nødvendigvis er det samme som en stamme. Naturgivne grænsezoner i form af skov- og sumpområder, men også floder og fjorde, kan have adskilt kulturgrupper. Også menneskeskabte barrierer som volde og borge kan have adskilt kulturgrupper ${ }^{4}$.

Et interessant spørgsmål er hvilke funktioner, som grænsezoner 
samt natur- og menneskeskabte barrierer har haft - herunder som grænse i forhold til hvem og hvad. Det kan også bidrage til at øge forståelsen for samspillet med transportkorridorerne. Grænsezoner og barriererne har haft en række funktioner - bl.a. økonomisk, militært og politisk, psykologisk, kulturelt og kommunikativt ${ }^{5}$.

Naturen, kulturlandskabet, erhvervsmæssige aktiviteter og bosætning indgår i en gensidig vekselvirkning, og områders særpræg inden for økonomi, erhverv, bebyggelsesmønstre m.v. skaber specialisering og arbejdsdeling mellem områderne ${ }^{6}$. Tilstedeværelsen af grænsezoner $\mathrm{i}$ form af skove, overdrev og vådområder m.v. er påvirket af behovet og mulighederne for at udnytte de pågældende områders potentialer. Grænsezoner som f.eks. skove har været interessante og nødvendige i den basale, daglige økonomi p.g.a. behovet for ressourcer som jern, tørv, græs, løvhø og træ. Betydningen af disse områder fremgår af de danske landskabslove fra 1200-tallet, som indeholder mange regler for bl.a. skovenes brug og anvendelse - regler, som nogle mener, går tilbage til i hvert fald vikingetiden ${ }^{7}$. I Jernvedskoven $i$ Slesvig-Holsten er der påvist jernudvinding $\mathrm{i}$ jernalderen, vikingetiden og middelalderen ${ }^{8}$. Grænsezoner - i nogle tilfælde i kombination med befæstningsanlæg og naturskabte barrierer - har desuden haft militære og politiske formål. Politisk har de adskilt stridende parter - og dermed reduceret mulighederne for kontakt og stridigheder, men kan også have indgået som led i et grænseforløb. Zonerne har også kunnet indgået som et led i det militære beredskab. I mange tilfælde har der indgået både militære og politiske hensyn. Allerede de antikke kilder nævner forskellige former for grænsezoner. Således omtaler Cæsar sump- og skovområder som en beskyttelseszone mellem to stammer. Tacitus beskriver i det 1. århundrede, at en række stammer var beskyttet af floder og skove ${ }^{9}$. Ofte blev germanske øde- og skovområder kombineret med befæstningsanlæg som volde, diger, borge, grave m.v. Til beskyttelse af Frankerrigets grænser etablerede kongemagten fra slutningen af 700-tallet såkaldte "mark«-er rundt om hele riget, som var en sikring af grænsen mod landets ydre fjender $\mathrm{i}$ form af anlæggelse af borge $\mathrm{i}$ eksisterende store skovområder og andre former for ødeområder ${ }^{10}$ - d.v.s. at eksisterende skov- og ødeområder blev brugt i et politisk og militært øjemed. Netop navnet »Danmark «betyder "Danernes grænseskov" og sigter sandsynligvis til grænseskovene i Sydslesvig - d.v.s. at grænsen mod nord var organiseret som en mark ${ }^{11}$. Tilsvarende var grænsen mod slaverne etableret 
som en »mark « i den store Jernved-skov - Limes Saxonia i Øst-hol$\operatorname{sten}^{12}$.

Psykologiske faktorer kan forstærke de økonomiske og militære faktorer, hvor forestillinger om uhyrer og sygdomme fremmer frygten for området. Naturen og naturkræfter er blevet tillagt mange egenskaber, hvor f.eks. store skove i gammel tid blev opfattet som noget særligt og dæmonisk. I middelalderlige tekster ses ødemarken som modsætningen til civilisationen ${ }^{13}$. Også det daglige liv var præget af sådanne ideer. Indmarken var det kendte, dyrkede område omkring gårdene og landsbyen, mens udmarken var det ukendte - modsætningen til det kendte - uden for indmarken ${ }^{14}$. Jernvedskoven i det sydlige Slesvig har samme navn, »Jernved «, som den grænseskov, der i den nordiske mytologi var grænseskoven, som adskilte menneskenes verden, Midgård, fra Udgård, hvor jætterne boede ${ }^{15}$. Der er dog ikke nødvendigvis en sammenhæng til den nordiske mytologi, da jernforarbejdning og smedning i store skove i udmarken i gammel tid blev opfattet som noget særligt og dæmonisk. Der er snarere tale om stednavne, der opstod på baggrund af menneskelige aktiviteter med et mytologisk indhold ${ }^{16}$. Kulturelt kan grænsezoner have adskilt forskellige kulturgrupper, men kan også have været kontaktzone for udveksling af ideer og gods. Kommunikativt interessante steder er tæt på vejforløb og vandveje eller på grænsen mellem områder med forskellig natur. Her kan der kommunikeres magt over ressourcer, produktion og sakrale forhold. I perioder, hvor nye magtsystemer bygges op, kan der også være behov for at demonstrere og kommunikere magt. Det kan være i form af gravhøje, høvdinge- eller våbengrave m.v. eller rituelle og religiøse funktioner, hvor der nedlægges specielt rige gaver eller udføres særlige handlinger ${ }^{17}$.

\section{Farrisskoven og Jernvedskoven som grænsezoner i Slesvig}

Slesvig har i lighed med det øvrige Nordeuropa haft grænsezoner i form af store skove og andre former for ødeområder, bl.a. Farrisskoven ved Slesvigs grænse mod nord ved Kongeåen og Jernvedskoven ved sydgrænsen nord for Ejderen ${ }^{18}$. Har de haft samme funktion, når de netop var placeret ved Slesvigs grænser? I "Farrisskovens Saga « berettes $^{19}$, at det nordlige Slesvig var dækket af ufremkommelige skove, der: 


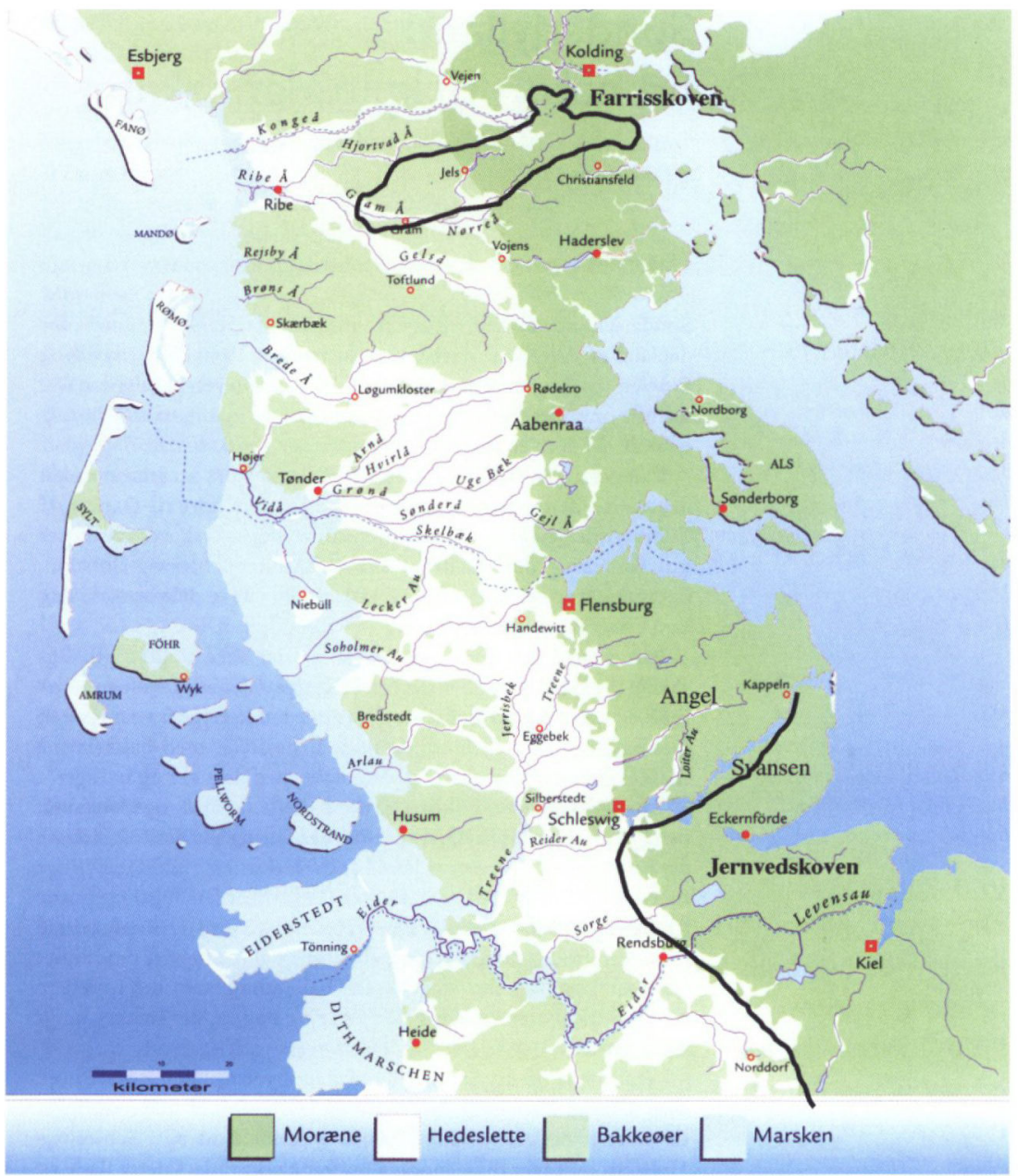

Figur 1. Farrisskoven og Jernvedskoven* $i$ Slesvig. Kilde: Meier 2000, s. 12, + egne indtegninger. *Note: Den vestlige afgrænsning er ikke kendt, og den østlige har muligvis dannet grænsen mod slaverne (Laur 1987, s. 14, og Benesch 1999, s. 12f).

"langt ind i Middelalderen stadig laa som et uigennemtrængeligt Øde og en uovervindelig Hindring for Færdselen, et Vildnis af Fyr, Eg og Bøg, af Hassel, Birk, Hvidtjørn og Kristtjørn; en Urskov i Ordets egentlige Betydning har den Kæmpeskov været. Ja, saa tæt var den - fortælles det - at en Rytter en Sommerdag ved Middagstid kunde ride i Skygge fra Rødding til Kalvslund Birke, og et Egern kunde tilbagelægge hele Vejen fra Lillebælt til Kalvslund uden at komme paa Jorden«. 


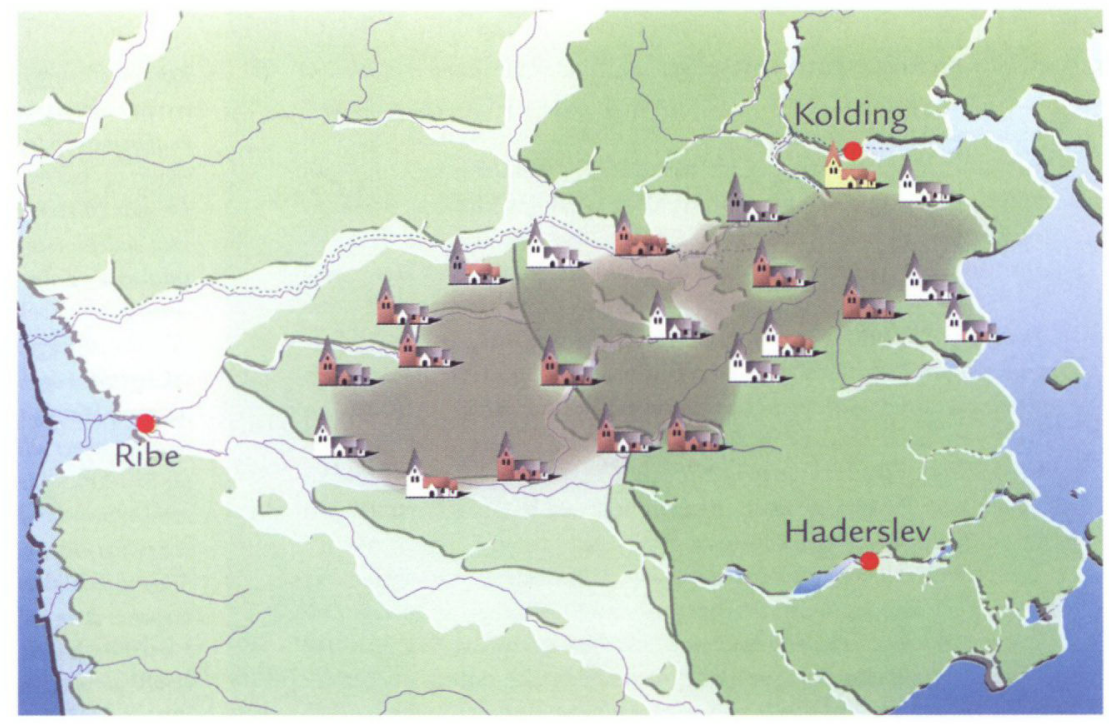

Figur 2. Udbredelsen af Farrisskoven $i$ tidlig middelalder illustreret ved kirkernes placering. Kilde: Poulsen 2003, s. 377.

Sagaen fortæller, at Farrisskoven i gammel tid lå syd for Kongeåen i det nordlige Slesvig mellem Kongeåen, Gram Å og Ribe Å. I en længde af ca. otte mil (ca. 60 kilometer) strakte Farrisskoven sig fra Lillebælt tværs over landet helt ud til Farup på Ribeegnen. Mod nord begrænsedes den af hedesletterne ved Kongeåen, og dens bredde sydpå ansloges til henved 1,5 mil (ca. 11,3 kilometer).

Som indicium på Farrisskovens eksistens og størrelse har udbredelsen af tidlige middelalderkirker været anvendt ${ }^{20}$. Hele vejen rundt om den formodede skov er der cirka tre til fem kilometer mellem hver kirke, hvorimod der på tværs af skoven er betydeligt længere, således over 15 kilometer mellem Øster Lindet syd for skoven og Skodborg nord for. Mellem kirkerne i Jels og Ødis og den i 1700-tallet nedrevne Højrup Kirke, der ligger i selve skoven, er der længere end normalt til de nabokirker, der omkredser skoven. Der er således fra Jels til Skodborg 7,3 kilometer, til Vamdrup 9,2 kilometer, til Rødding 9,7 kilometer og til Øster Lindet 6,7 kilometer. Dette kan næsten kun forklares med, at der endnu lå udstrakte skove mellem kirkerne.

Det første sikre, skriftlige vidnesbyrd om et sammenhængende skovområde - Farrisskoven - er kartografen Johannes Mejers kort over hertugdømmerne Slesvig og Holsten fra $1652^{21}$. Vi kan dog kom- 
me længere tilbage $\mathrm{i}$ tid. Ved at kombinere stednavne, arkæologiske fund og pollenanalyser kan det vises, at Farrisskoven først blev bebygget $\mathrm{i}$ løbet af middelalderen. Stednavne peger på, at dette skete $\mathrm{i}$ et stort skovområde. Dette understøttes af, at der er færre arkæologiske levn - og dermed en lavere menneskelig aktivitet - i Farrisskoven end $i$ et område uden om skoven ${ }^{22}$.

Vender vi blikket mod syd mod det sydlige Slesvig, har det 20 kilometer brede område mellem Ejderen og Danevirke været dækket af øde skovstrækninger. En række middelalderlige, historiske kilder peger samstemmende på, at skovområderne nord for Ejderen langt op i tid var en del af et langt større skovområde - Jernvedskoven i det sydlige Slesvig og Holsten. Adam af Bremen beskriver i 1000tallet området:

"(...) Danmark skilles fra vore landsmænd nordalbingerne ved floden Ejderen, der udspringer meget dybt inde $\mathrm{i}$ hedningernes skov Isarnho $\mathrm{o}^{23}$, som siges at strække sig langs det barbariske hav [d.v.s. Østersøen] frem til søen Slien. Isarnho-skoven begynder ved den sø hos Danerne, som hedder Slien, og som strækker sig helt hen til den stad hos slaverne, som hedder Lübeck, og til floden Trave. Lübeck ligger ved floden Trave (...). Floden Zuentian d.v.s. Schwentine-floden - kommer fra den sø, ved hvilken byen Plön ligger. Derpå løber den igennem Isarnho-skoven til Østersøen «. ${ }^{24}$

I forbindelse med korstogene i det 12. og 13. århundrede nævnes Jernvedskoven som en del af færden til Det hellige Land. Esbern Snare nævner $\mathbf{i}$ en opfordring til korstog således ca. 1190 Jernvedskoven, som »den udstrakte ødemark, der ligger mellem vendernes land, Holsten og Danmark « ${ }^{25}$. Fra 1100-tallet og fremefter er der bevaret skriftlige ejendomsbreve og lister over jordbesiddelser. Kong Valdemars Jordebog fra 1231 omtaler bl.a., at en del af kongens store landområde mellem Slien og Ejderen omfatter Fredslet, Kamp og den store Jernvedskov, som lå syd for Svansen ${ }^{26}$. Skoven omfattede området sydøst for Slesvig by mellem Slien og Eckernförde, Dänischen Wohld mellem Eckernförde og Kiel og videre over store strækninger til Kieler Förde og Trave-floden ved Lübeck. Den vestlige afgrænsning er ikke kendt, og den østlige har muligvis dannet grænsen mod slaverne ${ }^{27}$.

Jernvedskoven har helt klart fra i hvert fald den senere del af jernalderen og fremefter haft en både økonomisk, politisk og ikke mindst militærstrategisk funktion. Farrisskoven har ikke haft samme politiske og militære betydning, men har i højere grad haft en lokal betyd- 
ning. De to skoves placering ved Slesvigs grænser har således ikke givet sig udslag i samme funktion. Hvorfor dette har været tilfældet, kan vi komme nærmere ved at se på grænsezonernes forhold til transportkorridorer, spærrings- og kontrolanlæg og voldsteder/borge.

\section{Volde som kontrolanlæg og politisk magtsymbol langs med Hærvejen}

Hærvejen er den ældgamle og vigtigste færdselsåre i Jylland med både økonomisk, politisk og militær betydning. Langvoldene - Olgerdiget og $Æ$ Vold - har haft til formål at kontrollere den nord-sydgående færdsel ad Hærvejen og kan i tidlig ældre romersk jernalder have markeret en politisk og kulturel grænse mellem Anglerriget og Over Jerstal-kredsen.

Store anlæg som langvoldene har krævet, at der stod en centralmagt med ressourcer bag. Det må have været for at kontrollere Hærvejen som den vigtige færdselsåre - både økonomisk, politisk og militærmæssigt. Skove har kunnet være et led i det militære beredskab.

En effektiv samfærdsel og transportveje både til lands og vands har altid været afgørende for handel, forsvar og kommunikation i øvrigt. Indtil nyere tid har vand forbundet, mens land og ikke mindst landbarrierer i form af skove, vådområder m.v. har adskilt. Effektiv kontrol med færdslen i transportkorridorer har været en særdeles central og vigtig forudsætning for kontrol og styring af samfundet. Kontrollen med de landbaserede transportkorridorer påvises især arkæologisk ved langvolde, voldsteder og borge ved transportkorridorerne. I Slesvig findes en række anlæg af denne type. Hærvejen er den vigtigste og ældgamle transportvej. Langvoldene Olgerdiget, $Æ$ Vold og Danevirke er vigtige, landbaserede spærrings- og kontrolanlæg i tilknytning til Hærvejen. Endelig findes en række borge og voldsteder langs Hærvejsstrøget.

Udnyttelse af landskabet ved passager ved vandløb og vådområder har været grundlaget for etablering af de forhistoriske vejstrøg. Færdslen foregik i færdselskorridorer, der lå som brede bælter af hjulspor afgrænset af landskabelige barrierer som skove, søer, vandløb, mosedrag og andre vådområder. Generelt tog vejkorridorerne hensyn til vandskel og topografi, herunder undgåelse af højdedrag. Når et vejspor var opkørt og ufremkommeligt, opfyldtes vejsporet, eller man kørte et nyt spor op ved siden af. Vejanlæg er arkæologisk en forholds- 


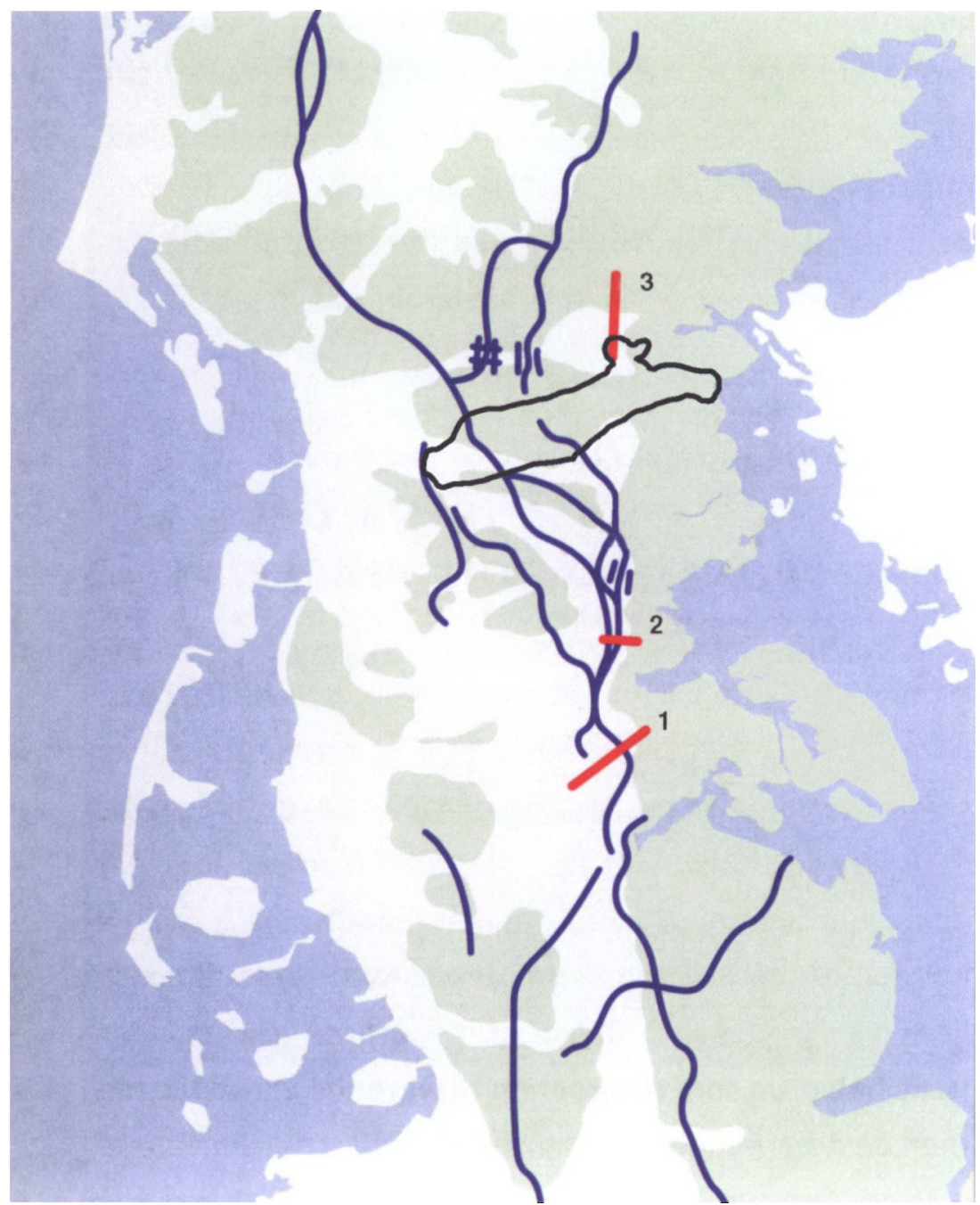

Figur 3. Den vigtigste nord-sydgående fardselskorridor - Hærvejen - samt langvolde fra romersk jernalder $i$ Slesvig. Kilde: Jorgensen 2003, s. 204. Note: 1. Olgerdiget. 2. Æ Vold. 3. Trældiget. Det gronne område er moræne, og det hvide er marsk og hedearealer.

vis veldokumenteret fundtype $\mathrm{i}$ forhistorisk og historisk tid, men kan som oftest kun påvises $i$ vådområder, ved vadesteder eller andre vanskeligt passable steder, hvor det har været nødvendigt at sikre og understøtte vejen med sveller, brolægning eller risflet ${ }^{28}$.

Hovedfærdselsårerne i Jylland knytter sig fra forhistorisk tid og mid- 
delalderen til nyere tid primært til færdselskorridorerne langs Hærvejen - »hærvejsstroget«. Vejen menes at have flyttet sig frem og tilbage - og måske har der været flere parallelle forløb samtidig. Hærvejen er den ældgamle færdselsåre i Jylland, og dens betydning ses af, at den mange steder er flankeret af bronzealderhøje og våbengrave fra ældre jernalder ${ }^{29}$. Formålet har været at kommunikere magt over ressourcer, produktion og sakrale forhold. Betydningen af Hærvejen ses også af, at der er investeret betydelige ressourcer $i$ opførelse af Olgerdiget samt $i$ vedligeholdelse, forstærkninger og ændringer. Til etablering af palisade-anlægget vurderes det, at der er brugt 90.000 egetræspæle, og ved udgravningen af graven har der skullet flyttes $15.000 \mathrm{~m}^{2}$ jord. Etablering af diget har været af samme dimensioner som f.eks. vikingetidsborgen Trelleborg ${ }^{30}$. Hærvejens militære og handelsmæssige betydning i perioden fra Kristi fødsel til ca. år 600 er det vanskeligere at sige noget nærmere om.

Hærvejens forløb fra Jelling til Øster Immervad synes op til en gang i middelalderen at have omfattet et hærvejsstrog igennem Farrisskoven fra Skodborg over Jels til Immervad. Desuden har der været en nordvest-sydøstgående diagonalvej fra Ribe til Toldsted i nærheden af Urnehoved ved Tinglev og en østlig vej ${ }^{31}$. En indikation på Hærvejsstrøget igennem Farrisskoven op til engang i middelalderen er delingen af Slesvig på tværs mellem bispedømmerne i Slesvig og Ribe. Delingen skete på tværs af herredsgrænserne, og sognene Oksenvad, Jels og Skodborg med hærvejsstrøget kom til at høre under Slesvig bispedømme ${ }^{32}$. Købstædernes opståen i vikingetiden og middelalderen medførte store ændringer i Hærvejens forløb. Den midterste del af hærvejsstrøget igennem Farrisskoven blev i senmiddelalderen stort set opgivet af den gennemgående fjerntrafik, mens Ribe, Kolding og Haderslev blev både endestation og udgangspunkt for den fjerntgående færdsel - primært oksetransporter ${ }^{33}$.

Langvolde - eller såkaldte folkevolde, som der er ca. 60 af i Jylland, optræder i forbindelse med naturlige forhindringer i landskabet, f.eks. moseområder og vandløb, og spærrer farbare områder. Det er karakteristisk, at hovedparten ligger ved vandskellet og følger Hærvejens forløb. I vådområder er vejspor blevet samlet til en enkelt bane ved overgangsstederne, og på disse steder har det været nemt at kontrollere og regulere færdslen til og fra et bestemt område. På det faste land har der været en regulering og samling af færdslen ved spærringer i form af kilometerlange volde. Spærringerne har været anlæg med vold, grav 
og palisader, der afspærrede mulige færdselskorridorer mellem landskabelige barrierer. Færdslen blev således ledt til kontrollerede passager $^{34}$.

To eksempler på sådanne langvolde findes i Slesvig - Olgerdiget og $Æ$ Vold. Begge ligger i tilknytning til Hærvejsstrøget. Olgerdiget ved Tinglev og $Æ$ Vold 15 kilometer nord for Olgerdiget vest for Genner er strategisk landskabsmæssigt placeret mellem de vestlige eng- og marskområder og det østlige morænelandskab. Digerne har forbundet landskabelige barrierer - og dermed udgjort en effektiv hindring for den nord-sydgående færdsel på Hærvejen ${ }^{35}$. Olgerdiget er det største langvoldsanlæg fra romersk jernalder. I luftlinje dækker anlægget en strækning på 12 kilometer, og heraf er 7,5 kilometer dækket af palisader af tætstillede egetræsstolper. På hele strækningen er der tre rækker af palisader og i mange tilfælde fem - ofte er to rækker dobbelte. Palisaderne stod nordvestligt foran den brede, fladbundede grav på hvis anden side, der visse steder var en lav vold. Der synes at have været porte nogle steder i palisaderækkerne, hvor Hærvejen havde sit forløb ${ }^{36}$. Den ældste datering af palisaderne viser, at dele af Olgerdiget blev bygget allerede i første århundrede e.Kr. ${ }^{37}$. $€$ Vold kan i dag følges over et par kilometer og har bestået af en $4 \frac{1}{2}$ meter bred tørgrav op til $1 \frac{1}{2}$ meter dyb. Gravens dybde har været størst på højtliggende områder. Over store dele af forløbet er der også spor af palisadehegn, der har ligget 3-6 meter nord for graven. På sydsiden af graven er der visse steder påvist en nu meget nedpløjet vold. $Æ$ Vold kan p.t. dateres til mellem 150 e.Kr. og slutningen af det 3. århundrede ${ }^{38}$. Der foreligger ikke dokumentation for, at hele anlægget med grav, vold og palisader er samtidig, men det kan være det.

Fællestræk ved Olgerdiget og $Æ$ Vold er, at de har været knyttet til Hærvejen. Voldenes forskellige orientering må tilskrives forskellige landskabelige forhold. Digerne har udgjort effektive spærringer af vigtige færdselskorridorer og kan have haft forskellige funktioner og eventuelt kombinationer heraf: Militære funktioner, som territorielle markører eller som færdselsspærringer. Anlæggenes militærstrategiske - forsvars- og angrebsmæssige - funktion synes at have været lille. Anlæggene har bl.a. været relativt lette at overskride af en større angrebsstyrke og svære at forsvare, da gravene var tørre og fladbundede, og de har dermed ikke været en effektiv barriere. Der har været uenighed om hvilken side af Olgerdiget og $Æ$ Vold, der har været rettet mod en eventuel fjende. Ses voldenes placering $i$ forhold til 
det omgivende terræn, vil et højtbeliggende terræn bagved volden og lavere vådområder foran være til forsvarerens/digebyggerens fordel. Dette taler for, at Olgerdiget er bygget af folk fra syd vendt mod folk nordvest for diget, mens det modsatte gør sig gældende ved $Æ$ Vold ${ }^{39}$.

Olgerdiget og $Æ$ Vold kan også have markeret en politisk og kulturel grænse. Set $i$ lyset af både Olgerdigets og $Æ$ Volds strategiske, landskabsmæssige placering ved Hærvejsstrøget synes anlæggene at have været færdselsspærringer med den primære funktion at kontrollere den nord-syd-gående trafik - måske som handels-/toldgrænse. I Olgerdiget er der netop påvist større og mindre åbninger ved Hærvejen, hvor færdslen kan være blevet ledt igennem ${ }^{40}$.

Sættes anlæggene og skovene i relation til den politiske udvikling i Slesvig fra ældre romersk jernalder til tidlig middelalder kan de i bestemte tidsafsnit give et bidrag til forståelse af den politiske udvikling fra de små politiske enheder $i$ ældre romersk jernalder til et dansk rige fra engang i 600-tallet. Opførelse af de store anlæg har forudsat en betydelig politisk magt, som både har haft ressourcerne og magten til at få dem etableret og haft en interesse deri.

\section{Den politiske udvikling i Slesvig}

I ældre romersk jernalder $\mathrm{i}$ tiden fra omkring Kristi fødsel til ca. år 150 kan der mellem Kongeåen og Ejderen udskilles tre, muligvis fire, lokalgrupper: Det sydvestlige Vadehavsområde (Vestkredsen), det centrale og østlige Slesvig (Angel), Over Jerstal-kredsen i Nordslesvig samt muligvis Als. I det arkæologiske materiale viser det sig ved forskelle i byggeskik, lerkarornamentik og gravskik ${ }^{41}$. Over Jerstal-kredsens sydgrænse ${ }^{42}$ kan på baggrund af arkæologiske fund, som kun findes entydigt $\mathrm{i}$ områderne nord og vest for Olgerdiget, fastlægges $\mathrm{i}$ en linje fra Vidåen ved Tønder til Aabenraa og mod nord sandsynligvis ved Kongeåen. Dateringen af Olgerdiget til det 1. århundrede tyder på, at fra engang i det 1. århundrede har grænsen mellem Anglerriget og Over Jerstal-kredsen gået ved Olgerdiget $\mathrm{i}$ øst og $\mathrm{i}$ vest ved Videåen, mens våd- og hedeområderne i den midterste del har dannet en naturlig, ubeboet barriere ${ }^{43}$. Set $i$ lyset af Olgerdigets placering $i$ landskabet er det anglerne, der har opført diget rettet mod nord.

I Slesvig tegner der sig i lighed med andre dele af det germanske område i ældre romersk jernalder indtrykket af mindre stammeområder, 


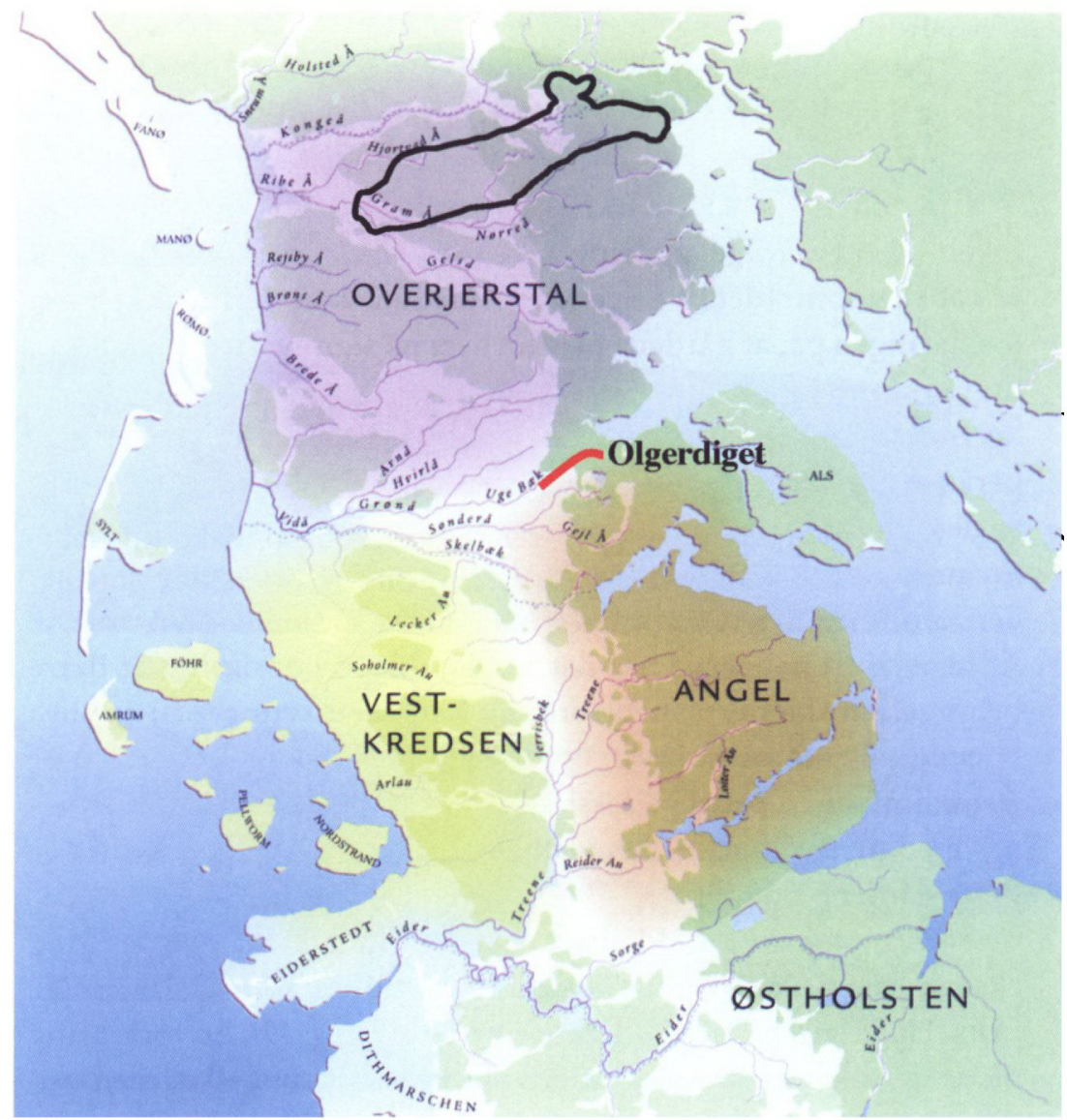

Figur 4. Lokalgrupper i Slesvig $i$ ældre romersk jernalder. Kilde: Ethelberg 2003, s. 167.

der blev styret af en aristokratisk krigergruppe ${ }^{44}$. De betydelige ressourcer, der er investeret i opførelse og vedligeholdelse af Olgerdiget og senere $Æ$ Vold, viser, at der har været betydelige interesser på spil og ressourcer til rådighed, hvor man bevidst på tværs af Hærvejsstrøget har ønsket at skabe en menneskeskabt barriere i forlængelse af de naturgivne barrierer $\mathbf{i}$ det vestlige Slesvig. Olgerdiget synes ikke at have haft nogen militærstrategisk betydning, men har sammen med de naturgivne forhold mod vest dannet en kulturel og politisk grænse. Kulturelt kommer det til udtryk igennem det forskellige, arkæologiske fundmateriale i hhv. Angeln og Over Jerstal-kredsen - dog med gliden- 


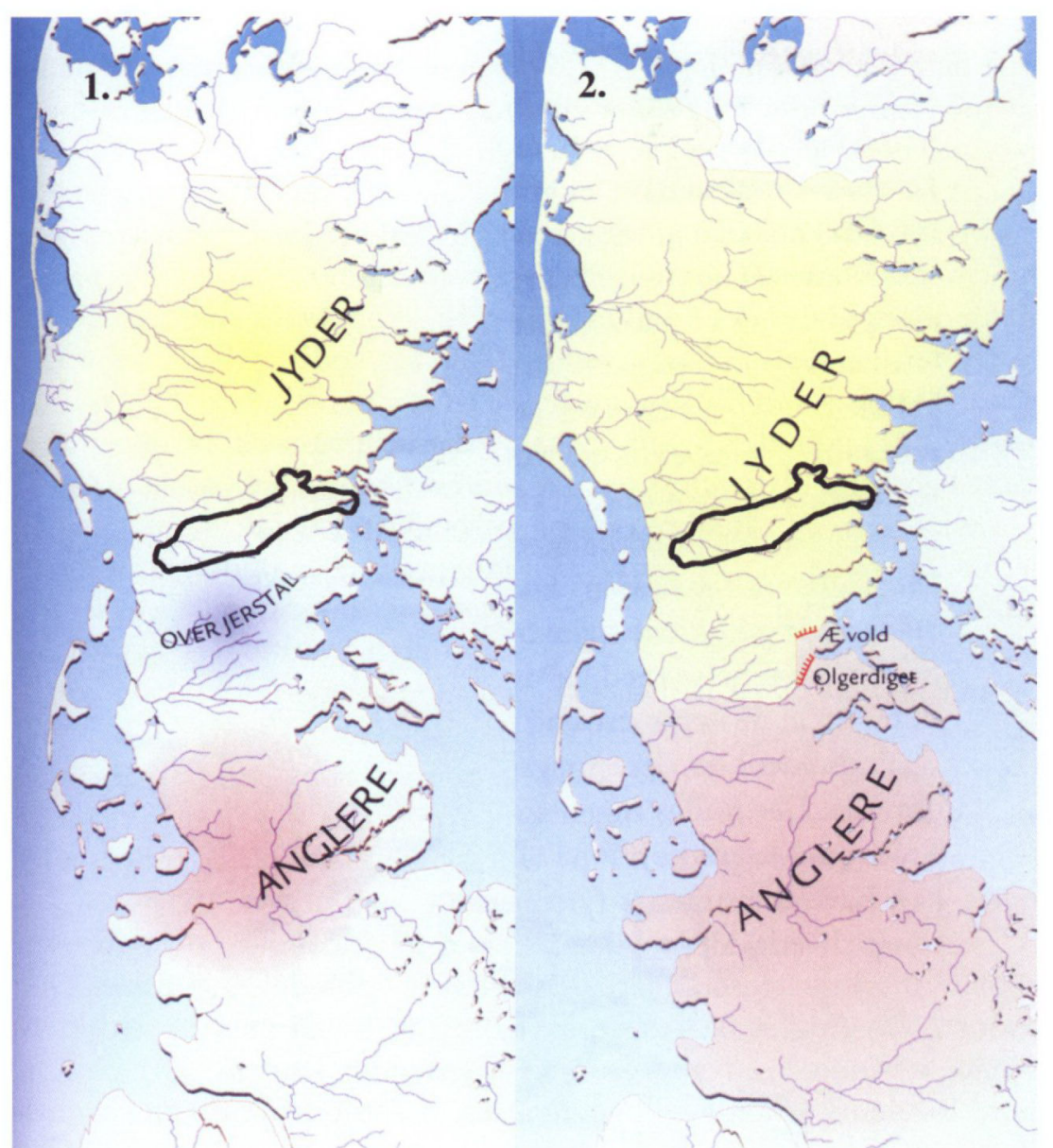

Figur 5.a. og 5.b. Lokalgrupper $i$ Slesvig fra overgangen mellem ældre og yngre romersk jernalder (1) og yngre romersk jernalder (2). Kilde vedr. kort: Ethelberg 2003, s. 223. Egne tidsangivelser.

de overgange, hvilket kan være udtryk for kontakt. Politisk set kan der have været et behov for at markere grænsen og skabe en bufferzone $i$ en periode, hvor nye magtstrukturer vokser frem og ekspanderer. En væsentlig funktion med voldene har også været kontrol med Hærvejen af politiske og økonomiske årsager. Handel langs Hærvejen er ikke påvist, men i denne periode er der stor import fra Romerriget til Danmark og Slesvig af bl.a. fornemme og udsøgte luksusvarer som romersk drik- 
keservice og glas. Hærvejen er vejen mod syd, og en del må være kommet denne vej til Danmark. De kostbare, importerede varer har de ledende i samfundet brugt til at vise magt og position i både samfundet og i gravene. Det har derfor været vigtigt at kontrollere færdsel og handel på Hærvejen. Måske har Olgerdiget endda været en toldgrænse ${ }^{45}$.

Farrisskoven kan have indgået i Over Jerstal-kredsens grænseområde mod nord. Nogle våbengrave fra det sidste århundrede før Kristi fødsel til første halvdel af det 2. århundrede e.Kr. ligger langs Hærvejsstrøget, herunder igennem Farrisskoven ved Jels til Skodborg ved Kongeåen, samt i Farrisskovens udkant mod syd og især nordøst ${ }^{46}$. Det må forklares med, at i perioder, hvor nye magtsystemer bygges op, kan der også være behov for at demonstrere og kommunikere magt.

Dele af Over Jerstal-kredsen blev i begyndelsen af yngre romersk jernalder fra ca. år 150 formentlig integreret eller underlagt den såkaldte jyske sydgruppe - kendetegnet ved en ensartet materiel kultur, som efterhånden kom til at omfatte området fra Randers Fjord i øst og Limfjorden i vest ned til grænsen mod Anglerriget. Den sydlige del blev opslugt ved Anglerrigets ekspansion mod nord ${ }^{47}$. I hele det germanske område sker der $\mathrm{i}$ denne periode opbygning af større og større stammeområder. I denne proces har der ligget en tiltagende centralisering og opbygning af et lederskab baseret på ledende fyrster og et krigeraristokrati ${ }^{48}$.

Fra Angel stammer de såkaldte Osterrönfeldt-huse, der i begyndelsen af ældre romersk jernalder har en udbredelse syd for linjen Vidåen, Olgerdiget og Aabenraa Fjord, og fra midten af ældre romersk jernalder og i yngre romersk jernalder kan de også påvises nord for denne grænse - $i$ begyndelsen af det 3 . århundrede så nordligt som Christiansfeld ${ }^{49}$ - lige syd for Farrisskoven. $Æ$ Volds tidligste datering til ca. år 150, samt at anlægget er rettet mod en fjende mod syd, kan pege på, at den jyske sydgruppe har opført anlægget - rettet mod Anglerriget. Anglerne har ekspanderet lidt længere mod nord, hvilket understøttes af udbredelsen af Osterrönfeldt-husene i i det 3. århundrede. Datering af de store våbenofferfund fra Thorsbjerg Mose over Nydam til Ejsbøl viser, at de tidligste skete længst mod syd, og ofringerne længere mod nord er senere. Nord for Kongeåen er billedet det omvendte, hvor større ofringer skete tidligst ved Illerup Ådal, mens de mere sydlige er senere. Tidsmæssigt mødes våbenofringerne fra syd og nord i tidsperioden mellem 250-310 i et område mellem Vejle og Haderslev ${ }^{50}$. 
Større skov- og ødeområder har mange steder dannet kulturelle grænser mellem forskellige områder, men politisk har der ikke været tale om skarpt geografisk, afgrænsede områder. Grænsen mellem Anglerriget og den jyske sydgruppe kunne fra engang i yngre romersk jernalder have gået ved Farrisskoven, der har dannet et kulturelt og politisk grænseområde mellem de to områder. $Æ$ Vold og Olgerdiget har haft til formål at kontrollere færdslen på Hærvejen. Perioden er præget af voldsomme kampe. Det fundne våbenudstyr i våbenofferfundene fortæller netop om hære, der i det 2 . århundrede kom fra områder syd for Danmark. Måske skal det ses i relation til Anglerrigets ekspansion mod nord og sydpå til Ejderen. I første halvdel af det 3. århundrede kom hærene fra det vestlige Skandinavien og $\mathrm{i}$ anden halvdel af det 3 . århundrede og begyndelsen af det 4 . århundrede fra det østlige ${ }^{51}$. Vedligeholdelsen af Olgerdiget og $Æ$ Vold samt søspærringer - Margrethes Bro og $\varpi^{\prime}$ Lei - i Haderslev Fjord i slutningen af 300-tallet og begyndelsen af 400-tallet viser, at der har stået en form for centraliseret magt bag ${ }^{52}$. Både Hærvejen og Farrisskoven har derfor givet haft stor militær betydning: Hærvejen for transport af hære, og Farrisskoven som en integreret del af det militære beredskab, da store skovområder har dannet naturlige barrierer for indtrængende fjender.

Fra midten af det 5 . århundrede spores en fundnedgang i det arkæologiske kildemateriale med bl.a. omlæggelse og nedlæggelse af bebyggelser - i Sydslesvig endda en dramatisk nedgang, men skattefund og fund af enkelte hængesmykker (brakteater) vidner om fortsat bebyggelse $^{53}$. Fundnedgangen er sat i forbindelse med anglernes, saksernes og jydernes udvandring til England - »Angulus desertus« fra midten af det 5. århundrede. Den engelske krønikeskriver Beda skriver således i 731 i en beskrivelse af Angel i Slesvig, at

"fra den tid af [antagelig fra midten af det 5. århundrede] og frem til $\mathrm{i}$ dag [år 731] skal området mellem saksernes og jydernes land have været forladt ${ }^{54}$.

Generelt er der enighed om, at udviklingen i Skandinavien følger udviklingen i det øvrige germanske område sydpå ${ }^{55}$. Fra det første møde mellem de germanske, slægtsbaserede stammesamfund og Romerriget $\mathrm{i}$ andet $\mathrm{g}$ første århundrede f.Kr. udviklede de germanske samfund sig $\mathrm{i}$ århundrederne efter Kristi fødsel til store, velorganiserede stammer med hære efter romersk forbillede. 
Vedligeholdelsen af Olgerdiget og $Æ$ Vold samt søspærringer Margrethes Bro og $\mathbb{E}^{\prime}$ Lei - i Haderslev Fjord fra slutningen af 300tallet og begyndelsen af 400-tallet viser, at der har stået en form for centraliseret magt bag ${ }^{56}$. I kampen om magten har kontrol med transportkorridorer og grænsezoner været vigtig.

\section{Danevirke som militært redskab}

Med opførelsen af Danevirke i 600-tallet understreges en stærk politisk magt i Danmark/Slesvig. Samspillet mellem Danevirke, Hærvejen og Jernvedskoven har været vigtigt, især af politisk og militærstrategisk betydning. Danevirke har haft både en politisk og militær betydning samt har kontrolleret såvel den nord-sydgående som den øst-vestvendte handel.

Det militære beredskab og indsats på land og til vands må ses i en integreret helhed. På land har der været behov for at kunne dæmme op for fjender igennem kontrol med svært passable områder og dermed kontrol med det overordnede vejnet. Store skovområder som Jernvedskoven og Farrisskoven har kunnet indgå som en integreret del af dette system ved at danne en svær uigennemtrængelig naturbarriere. Brede kystskovbælter på to til tre kilometer har kunnet supplere dette system og beskytte indlandet mod angreb fra kysten ${ }^{57}$.

Danevirke, der betyder danernes værn, er betydeligt ældre end 808 , hvilket den traditionelle forskning gik ud fra, og er resultatet af ca. fem hundrede års byggevirksomhed fra midten af 600-tallet til ind i 1200-årene. Komplekset består af langvolde fra vidt forskellige tider, og mange gange er partier af voldene blevet repareret eller udbygget, så de passede til tidens forsvarsbehov og krigsteknik ${ }^{58}$.

Danevirke beskyttede sammen med udnyttelse af de naturgivne forhold Danmarks sydgrænse ved Jyllands rod, hvor den jyske halvø er smallest. Voldforløbene, som har en samlet længde på ca. 30 kilometer, strækker sig fra Hedeby ved bunden af Slien i ost til Rheideog Treene-floderne i vest. Mod vest spærredes færdslen af åer, marskområder og brede, fugtige ådale og mod øst af Slien. I det smalle forløb mellem disse to landskabsmæssige barrierer løb Hærvejen. Det ca. 20 kilometer brede område fra Danevirke til Ejderen sydpå var dækket af øde skovstrækninger ${ }^{59}$. Opførelsen af Danevirke er således sket bevidst ved at udnytte både de naturgivne barrierer og eksistensen af den store Jernvedskov. Hvor Hærvejen krydser Danevirke, 


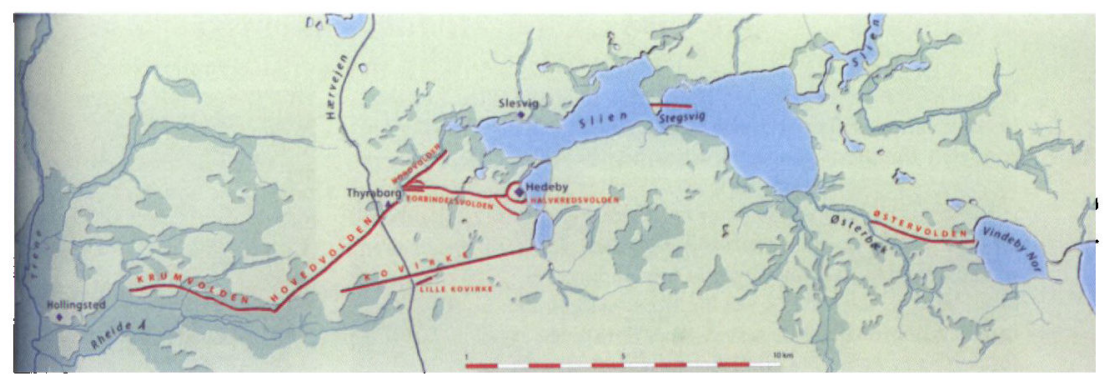

Figur 6. Det samlede Danevirkekompleks. De forskellige voldforlob er angivet med rødt. Kilde: Poulsen 2008, s. 45.

er der arkæologisk påvist en 4 meter bred port i Kovirke ${ }^{60}$. I Slien er fundet en 1100 meter lang søspærring - dateret til 737 samtidig med en udbygning af Danevirke. Søspærringen må ses som en integreret del af Danevirkekomplekset og går på tværs af Slien med to smalle passager. Søspærringen har haft et klart forsvarsmæssigt formål samt skullet sikre kontrollen med indsejlingen ${ }^{61}$.

\section{Borgenes og Danevirkes funktion i forhold til transportkorridorerne}

De forhistoriske og middelalderlige borge og voldsteder langs Hærvejen, herunder igennem og ved Farrisskoven, har haft det primære formål at kontrollere færdslen i transportkorridoren. I urolige tider $\mathrm{i}$ forhistorisk tid og middelalderen har borge og voldsteder været centrale steder som tilflugtssteder, forsvarsanlæg og kontrollen med geografiske områder. Borge og voldsteder kan også have haft en vigtig funktion i forhold til vejkorridorer, vandløb og vadesteder for at kontrollere færdslen. I det nuværende Danmark kendes omkring 1.000 borge og voldsteder fra jern- og middelalderen ${ }^{62}$. Borge og voldsteder omkranser Farrisskovens sydøstlige udkant.

Borge og voldsteder fra jern- og middelalderen har i Nordslesvig en udpræget østlig koncentration ved den østlige del af Hærvejen fra Immervad over Haderslev til Kolding samt Hærvejsstrøget igennem Farrisskoven over Jels til Skodborg-området. Særligt Jels Voldsted, der ligger på Hærvejsstrøget igennem Farrisskoven ved Jels Midtsø, har påkaldt sig interesse p.g.a. denne placering. Navnet Jels menes at betyde "Jarls sø", og på det grundlag har det været foreslået, at Jels 
Voldsted måske har været et af centrene for det sønderjyske jarledømme, der kendes allerede fra 1000-tallet. Ud fra få arkæologiske udgravninger og skriftlige kilder er det dog kun muligt at opfatte Jels Voldsted som et 1300 -tals voldsted ${ }^{63}$.

Koncentrationen af borge og voldsteder i tilknytning til Hærvejsstrøgets forløb øst for og igennem Farrisskoven må have haft til formål at kontrollere færdslen i transportkorridoren. Hvor Hærvejen krydser Danevirke, har det været muligt og vigtigt at kontrollere trafik og handel. Ved Danevirke har det således været muligt at kontrollere både den nord-sydgående trafik og handel og den øst-vestgående handelsrute mellem Øster- og Nordsøen. Måske har der tillige været en toldfunktion ved Danevirke. Sidst, men ikke mindst, må Hærvejen set i relation til Danevirke have haft en militær funktion for tilførelse af tropper m.v.

Der har været vitale handelsmæssige interesser ved Hedeby og senere Slesvig by. Eksport via Hærvejen i form af oksetransporter er ikke dokumenteret før i 1200-tallet, men det må forudsættes, at der må have været en nord-sydgående handel tidligere. Tillige har der været en øst-vestgående søhandelsrute mellem Østersøen og Nordsøen, som fra øst gik via Ejderen til Treene-floden, hvor der var mulighed for at sejle ud i Nordsøen. Udskibningshavnen mod vest var Hollingsted nord for Nordsøen ${ }^{64}$. Opførelsen af Danevirke har en militærstrategisk baggrund i den stigende udbygning og konsolidering af kongemagten i Danmark i det syvende århundrede samt de stigende konflikter og krige i de efterfølgende århundreder. Med Danevirke skabtes en egentlig politisk grænse for kongeriget Danmark mod syd, hvor den store Jervedskov indgik og bevidst politisk og militært blev brugt som led i sikring af grænsen.

\section{Danmark - "grænseskov «}

Netop navnet »Danmark « betyder »Danernes grænseskov« og sigter sandsynligvis til grænseskovene i Sydslesvig ${ }^{65}$. Med den slaviske indvandring $\mathrm{i}$ det $6 . \operatorname{og} 7$. århundrede $\mathrm{i}$ områderne øst for Elben $\mathrm{i}$ Holsten og Saale og den saksiske i det 5. århundrede mellem Weser og Elben og videre nordpå, kom Ejderen til at danne grænsen mod Jylland mod nord. I slutningen af 700-tallet erobrede Karl den Store det saksiske område, og i 811 blev Ejderen anerkendt som grænsen mellem det danske kongerige og Frankerriget ${ }^{66}$. Den danske konge havde grund 
til at være på vagt ved grænsen - særligt i tiden fra midten af 1000tallet til 1157, hvor Valdemar den Store blev konge og skabte en stærkere dansk kongemagt. Jarlerne eller hertugerne i Slesvig havde på kongens vegne hovedansvaret for Hedeby/Slesvig og forsvaret af Danevirke ${ }^{67}$. Politisk set var der en grænse mellem Danmark og Slesvig på den ene side og naboerne på den anden side, men det var en åben grænse. Ad Hærvejen og skibsvejen var der en stor udveksling af personer, varer og ideer. Kristendommens indførelse i Danmark og Slesvig er et meget illustrativt eksempel ${ }^{68}$.

I og omkring Farrisskoven havde kongen i henhold til kong Valdemars jordebog i 1200-tallet meget små besiddelser, men havde til gengæld store besiddelser i Sydslesvig, især på halvøen Angel samt syd og sydvest for Slien, herunder dele af Jernvedskoven. I Farrisskovområdet og på Angel var der tale om patrimonium-gods - d.v.s. fædrenegods, som arvedes og deltes i kongeslægten. Syd for Slesvig by var der store kongelev-besiddelser, der var knyttet til det kongelige embede $^{69}$. Kongemagten havde betydelige økonomiske, militære og politiske interesser i handelsbyen Slesvig og Danevirke, hvorfor det har været politisk og økonomisk interessant at have meget krongods i dette område. De betydelige kongelev-besiddelser ned mod Ejderen har sammen med Danevirke haft et sikkerhedsmæssigt og militært formål. Samtidig kan det være økonomisk begrundet $i$ behovet for øget produktion og skatteindtægter, at kongen i 1100-tallet tillod den holstenske kolonisation i den kongeligt ejede Jernved-skov ${ }^{70}$.

I Farrisskoven har kongemagten sandsynligvis ikke udnyttet sin ejendomsret til almindinger - d.v.s. fællesskov - $\mathrm{i}$ henhold til det kongelige regale om, hvad ingen ejer, ejer kongen, hvorved afgifter af nyanlagte bebyggelser $\mathrm{i}$ almindingen skulle tilfalde kronen ${ }^{71}$. Farrisskoven har for kongemagten været politisk og økonomisk uinteressant. Dette skal vi se nærmere på i det følgende afsnit.

\section{Farrisskovens funktion}

Farrisskoven har sammenlignet med Jernvedskoven ikke haft samme politiske og militære betydning, selvom den ligger ved grænsen mellem Slesvig og Nørrejylland. Den har i højere grad haft en lokal økonomisk betydning $\mathrm{i}$ et differentieret bebyggelsesmønster og viser, hvordan udnyttelse af ressourcerne og bebyggelsesmønstret tilpasser sig ændrede økonomiske behov. 


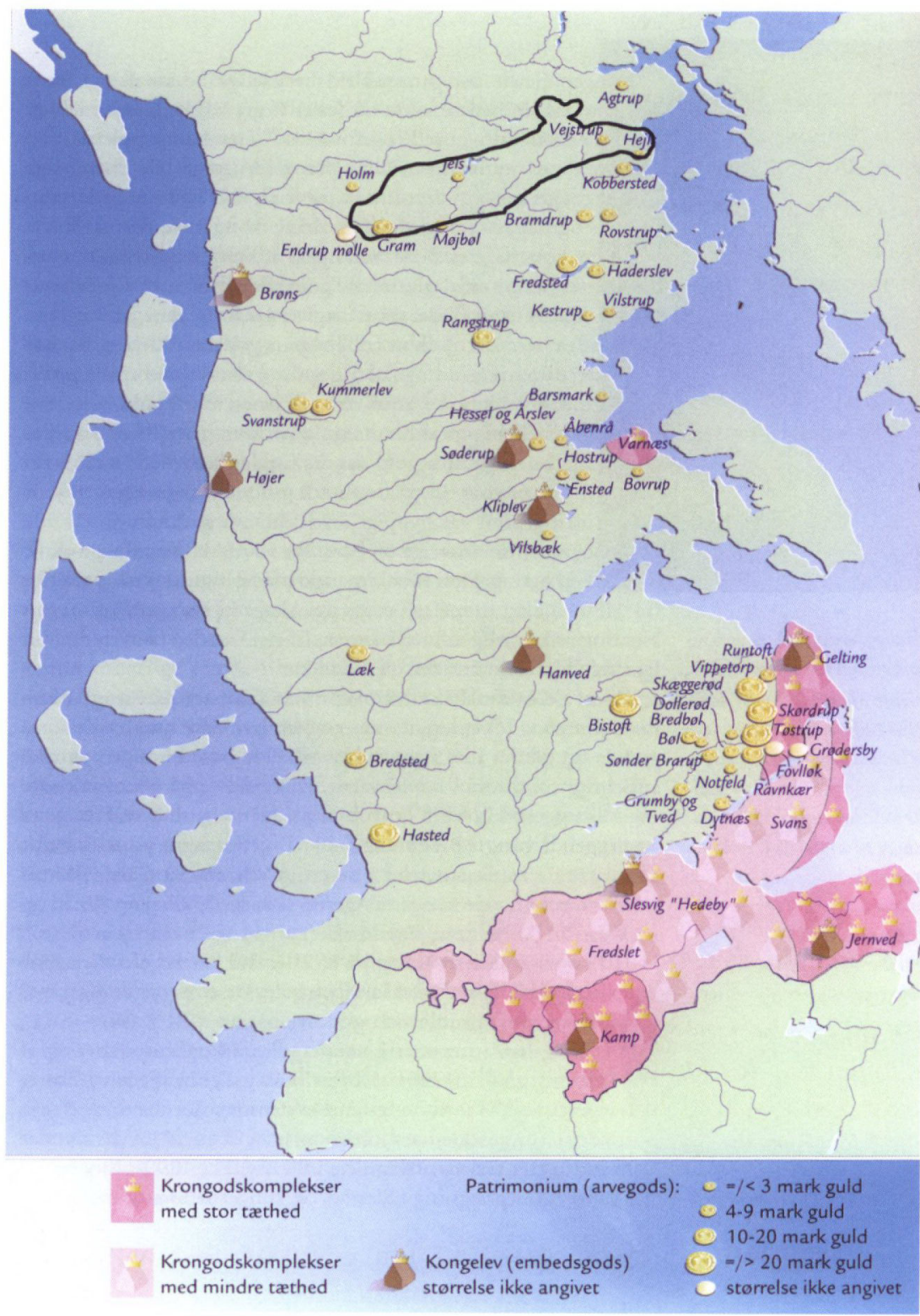

Figur 7. Krongods i Slesvig efter Kong Valdemars Jordebog 1231. Kilde: Poulsen 2003, s. 404. 
Ved at anlægge et bebyggelsesmæssigt perspektiv kan der tegnes et billede af den forhistoriske bebyggelse og bebyggelsesmønster - og dermed, hvad skovens funktion bl.a. har været. De fortidige landsbysamfund var opdelt i bosætningsområder - ejerlav - hvor der var adgang til en række forskellige ressourcer som marker, engarealer, græsnings- og skovområder. Nogle åbne landskaber gav mulighed for agrarproduktion, andre med hede eller eng var særligt egnede til animalsk produktion, og store skovområder har givet basis for dyrehold, jagt, træ og produkter som trækul og tjære ${ }^{72}$. Landskabslovene fra 1200tallet bl.a. Jyske Lov fra 1241 - indeholder en lang række detaljerede bestemmelser om skovenes ejendoms- og brugsret, bevidst skovpleje, nyopdyrkning, tømmer og træfælding, dyrehold, løvfodring og jagt i skoven samt anvendelse af en række andre ressourcer ${ }^{73}$.

Det generelle billede af bebyggelsesmønstret i Nordslesvig er, at fra midten af ældre jernalder bliver landsbyerne mindre, men samtidig stiger antallet af landsbyer. I begyndelsen af yngre jernalder synes landsbyerne at blive erstattet af enkeltgårde, men i sidste halvdel af det 3 . århundrede træder landsbyerne igen frem $i$ fundbilledet. Et meget karakteristisk træk er, at fra det 2. århundrede og op i middelalderen har der rundt om landsbyerne ligget et større eller mindre antal enkeltgårde, som sandsynligvis har indgået i et samspil med landsbyerne ${ }^{74}$.

Såkaldte bebyggelsesudvidende stednavne - med endelser som -bøl og -torp - viser, at der i vikingetid og tidlig middelalder skete en omlægning af bebyggelsen i området uden om Farrisskoven, hvor der blev anlagt en række nye bebyggelser fra eksisterende landsbyer i udkanten af det enkelte ejerlavs ressourceområde. Yngre skovindikerende stednavne med endelser som -skov, -lund/-ved, -rød, og -holt fra tidlig middelalder viser, at der skete en ekspansion af bebyggelsen i form af ofte mindre rydninger $i$ egentlige skovområder - både $i$ området uden om Farrisskoven og i Farrisskoven ${ }^{75}$.

Der er relativt sparsomme oplysninger om bebyggelsesmønstret $\mathbf{i}$ Farrisskov-området. Det generelle bebyggelsesmønster i Nordslesvig, sammenholdt med udbredelsen af bebyggelsesudvidende og skovindikerende stednavne, kan dog vise en sammenhæn mellem de ældre landsbyer og de senere rydninger i skoven som led i et driftsøkonomisk fællesskab om udnyttelse af forskellige typer af ressourcer. Etablering af enkeltgårde eller et mindre antal gårde i rydninger i ubebyggede områder som skove kan være sket på de etablerede landsbyers initiativ med henblik på større udnyttelse af skovens ressourcer. 
Egentlige landsbyetableringer i og omkring Farrisskoven må ses i lyset af den voksende befolkning i middelalderen og behovet for en større landbrugsproduktion ${ }^{76}$.

En opdeling af kulturlandskabet i nyere tid viser, at Farrisskoven primært har været et skovområde med små landsbyer og mange enkeltgårde ${ }^{77}$ - et billede, der genfindes i det arkæologiske fundbillede. Denne opdeling af kulturlandskabet kan give et fingerpeg om, at bebyggelsen i det skovrige Farriskov-område fra tidlig middelader kan have haft en arbejdsdeling og specialisering $i$ forhold til hedeområderne nord og syd for området samt kyst- og agerområderne mod øst. Hvert område har haft forskellige ressourcer, som alle har haft brug for i det daglige liv. Skovområder har haft træ, vildt, trækul og tjære, mens man $\mathrm{i}$ hedeegnene har levet af husdyrproduktion, og $\mathrm{i}$ ager- og kystområderne af kornavl, husdyr og fiskeri.

\section{Konklusion}

I artiklen har jeg beskrevet og vist samspillet mellem transportkorridorer og forskellige former for barrierer og kontrolanlæg fra ældre romersk jernalder til cirka år 1200 . Det kan dreje sig om både menneskeskabte og naturgivne forhindringer. Der er redegjort for Slesvigs store grænseskove mod nord og syd - Farrisskoven og Jernvedskoven - Hærvejen og befæstningsanlæg som Olgerdiget, $Æ$ Vold og Danevirke samt borge/voldsteder, der har ligget på strategiske steder og kontrolleret Hærvejen i Slesvig.

Grænser var til langt op i middelalderen større grænseområder ikke linære som i dag. Sådanne grænsezoner samt natur- og menneskeskabte barrierer, har haft en række funktioner - bl.a. økonomisk, militært og politisk, psykologisk, kulturelt og kommunikativt.

Hærvejen er den ældgamle og vigtigste færdselsåre i Jylland med både økonomisk, politisk, kulturel og militær betydning, og det har derfor været vigtigt at kontrollere den. Det er i det lys, at vi må se befæstningsanlæggene.

Langvoldene - Olgerdiget og $Æ$ Vold - har haft til formål at kontrollere den nord-sydgående færdsel ad Hærvejen og kan i tidlig ældre romersk jernalder have markeret en kulturel og politisk grænse mellem Anglerriget og Over Jerstal-kredsen. Danevirke har haft en politisk og militær betydning samt kontrolleret både den nord-sydgående og øst-vestvendte handel. 
De forhistoriske og middelalderlige borge og voldsteder langs Hærvejen, herunder igennem og ved Farrisskoven, har også haft det formål at kontrollere færdslen i transportkorridoren. Våbengravene ved Hærvejen fra ældre, romersk jernalder har haft til formål kommunikativt at vise magt - måske i en periode, hvor nye magtsystemer bygges op.

Slesvigs store grænseskov mod syd, Jernvedskoven, har helt klart fra $i$ hvert fald den senere del af jernalderen og fremefter indgået $i$ et samspil med både Hærvejen og Danevirke og haft en både økonomisk, politisk og ikke mindst militærstrategisk funktion. Slesvigs status som grænseregion har gjort det af afgørende betydning at sikre grænsen mod syd ved Ejderen. Grænsen mellem det danske rige og rigerne sydpå har haft flere lag, hvor Ejderen udgjorde første forhindring. Jernvedskoven har indgået som en militær bufferzone, hvor Danevirke har været sidste led i det danske forsvar vendt mod syd.

Farrisskoven har sammenlignet med Jernvedskoven ikke haft samme politiske og militære betydning, da det ikke på samme måde som mod syd har været afgørende at sikre grænsen mellem Slesvig og Nørrejylland. Den har i højere grad haft en lokal økonomisk betydning $i$ et differentieret bebyggelsesmønster og viser, hvordan udnyttelse af ressourcerne og bebyggelsesmønstret tilpasser sig ændrede økonomiske behov.

Samspillet mellem Hærvejen, befæstningsanlæggene og skovene kan i bestemte tidsafsnit ses i sammenhæng med den politiske udvikling fra de små politiske enheder $i$ ældre romersk jernalder til et dansk rige fra engang i 600-tallet. Store anlæg som langvoldene har krævet, at der stod en centralmagt med ressourcer bag. Det understøttes af andre former for arkæologiske udsagn. Med opførelsen af Danevirke i 600-tallet og den fortsatte ud- og ombygning i de næste 500 år ses både en stærk politisk magt i Slesvig og Slesvigs store politiske betydning som grænseregion for det danske rige.

\section{LITTERATUR OG KILDER}

Adam af Bremen ca. 1075: De hamburgske ærkebispers historie og Nordens beskrivelse, oversat af Carsten L. Henrichsen, 1968, Rosenkilde og Bagger, København.

Andresen, J. (et al.) 2008: »On the warpath. Terrestrial military organisation in prehistoric Denmark «, Compu- ter Applications and Quantitative Methods in Archaeology, konferencenr. 35, German Archaeological Institute.

Anspach, B. 2007: "Hollingstedt: Haithabus Tor zur Nordsee . I: CarnapBornheim, C. v. \& Segschneider, $M$. (hrsg.): Die Schleiregion. Land - Wasser-Geschichte, s. 139-143, Theiss. 
Becker-Christensen, H. 1981: Harvicjen $i$ Sonderjylland - et vejhistorisk studie - Fra Kongeaien til Danevirke, Institut for Grænseregionsforskning, Aabenraa.

Benesch, E. 1999: „Der Isarnho«, s. 1-35, Jahrbiicher für das ehemalige Amt Bordesholm.

Christensen, L. 2006: "Nye undersogelser af Olgerdiget - en langvold fra jernalderen «, s. 3-10, Sanderjysk Mănedsskrift.

Christoffersen, J. \& Porsmose, E. 1996: »Den fynske kystzones bebyggelsesmonstre i jernalder, vikingetid og middelalder «. I: Crumlin-Pedersen, O. (red., et al.): Atlas over Fyns kyst $i$ jernalder, vikingetid og middelalder, $\mathrm{s}$. 154-160, Odense Universitetsforlag.

Darby, H.C. 1934: »The Fenland Frontier in Anglo-Saxon England «, s. 185201, Antiquity 8.

Davies, W. \& Vierck, H. 1974: "The contexts of Tribal Hidage: Social aggregates and settlement patterns«, s. 223-293, Frïhmittelalterliche Studien 8.

Dobat, A.S. 2003: "Angulus non desertus! - Kontinuität und Zentralität in der jüngeren Eisenzeit Südschleswigs «, s. 113-138, Arkæologi i Slesvig, vol. 10.

Dobat, A.S. 2006: "Angulus non desertus! II. Erste ergebnisse der suche nach Siedlungen des 6. og 7. Jahrhunderts in Südschleswig ", s. 87-94, Arkzologi i Slesvig, vol. 11.

Domeier, K. \& Haack, M. 1963: Die Landkarten von Johannes Mejer, $\mathrm{Hu}$ sum, aus der newen Landesbeschreibung der zwei Herzogtümer Schleswig und Holstein zon Caspar Danckuerth D. 1652, Verlag Otto Heinevetter, Hamburg-Bergedorf.

Ethelberg, P. 2003: "Gården og landsbyen $i$ jernalder og vikingetid $(500$ f.kr. - 1000 e.kr.)«. I: Ethelberg, P. (et al.): Det sonderjyske landbrugs historie Jernalder, vikingetid og middelalder, b. 2 , s. 123-373, Haderslev Museum og Historisk Samfund for Sønderjylland, Haderslev.

Ethelberg, P. 2007: »Verteigungsanlagen und haustypen der älteren römischen kaiserzeit im ehemaligen her- zogtum Schleswig-Holstein«. I: Grünewald, C. \& Capelle, T. (hrsg.): Innere strukturen von siedlungen und gräberfeldern als spiegel gesellschaftlicher wirklichkeit «, "Akten des 57. internationalen Sachsensymposions von 26. bis 30. august 2006 in Muinster, s. 145153, Aschendorff, Münster.

Fabech, C. 1993: "Skåne-et kulturelt og geografisk grænseland i yngre jernalder og i nutiden «, s. 201-245, TOR.

Fabech, C. \& Ringtved, J. 1995: "Magtens geografi iSydskandinavien - om kulturlandskab, produktion og bebyggelsesmønster «. I: Resi. H.G.: Produksjon og samfunn. Om crverv, spesialisering og bosetning $i$ Norden $i$. dirtusen e.kr. Beretning fra 2. nordiske jernaldersymposium på Granavolden Gjestgiveri 7.-10. mai 1992, s. 11-37, Oslo.

Fritzbøger, B. 2004: A windfall for the magnates. The development of woodland ownership in Denmark c. 1150-1830, University Press of South Denmark.

Grau Møller, P. \& Porsmose, E. 1997: Kulturhistorisk inddeling af landskabet, Skov- og naturstyrelsen, Miljø- og Energiministeriet.

Hardt, M. 2001: "Mark«, s. 282-284, Reallexicon der Germanischen Altertumskunde, Walter de Gruytter, Berlin, New York.

Harrison, D. 2001: "Invisible boundaries and places of power: Notions of liminality and centrality in the early middle ages «. I: Pohl, W. (et. al., ed.): The transformation of frontiers. From late Antiquity to the Carolingians, s. 8394, Brill, Leiden/Köln/Boston.

Helmuth Andersen, H. 1992: "De glemte borge«, s. 19-30, Skalk nr. 1.

Helmuth Andersen, H. 2004: Til hele rigets værn, Moesgård og Wormianum.

Hermansen, K.M. 1947: Farrisskovens saga, Sønderjysk Månedsskrift, nr. 23, s. $161-176$.

Hoff, A. 1997: Lov og landskab - Landskabslovenes bidrag til forstielsen af landbrugs- og landskabsudviklingen $i$ Danmark ca. 900-1250, Århus Universitetsforlag.

Jantzen, C. \& Madsen, L.S. 1999: "Voldsteder i Vest- og Sonderjylland «. I: Jantzen C. (red., et al): Voldsteder $i$ 
Danmark. En vejoiser. Jylland II, s. 49281, Skippershoved.

Jensen, J. 2003: Danmarks Oldtid. Aldre jernalder 500 f.kr. - 400 e.kr., Gyldendal.

Jensen, J. 2004: Danmarks Oldtid. Yngre jernalder og vikingetid 400-1050 e.kr., Gyldendal.

Jöns, H. 1992/93: "Zur Eisenverhüttung in Schleswig-Holstein in vor- og frühgeschichtlicher zeit«, s. 41-55, OFFA, vol. 49-50.

Jørgensen, A.N. 2003: "Befæstning og kontrol af færdsel til lands og til vands i forromersk og romersk jernalder «. I: Jorgensen, L. (ed., et al.): $S e j-$ rens triumf. Norden i skyggen af det romerske imperium, s. 194-209, Nationalmuseet, København.

Jørgensen, B. 1994: Stednavneordbog, 2. udg., Gyldendals Røde Ordbøger, Gyldendal, København.

Kehne, P. 1999: "Grenze - § 3. Historisches a. terminologie «, s. 10-15, Reallexicon der Germanischen Altertumskunde, Walter de Gruytter, Berlin, New York.

Kramer, W. \& Hardt, N. 2007: "Das Danewerk - das grösste frühgeschichtliche Bauwerk Nordeuropas. Archäelogie und Geschichte des Danewerkes«. I: Carnap-Bornheim, C. v. \& Segschneider, M. (hrsg.): Die Schleiregion. Land - Wasser - Geschichte, s. 8695, Theiss.

Kratochwil, F. 1986: "Of systems, boundaries and territoriality: An inquiry into the formation of the state system«, s. 27-52, World Politics, vol. 39:1.

Lund Hansen, U. 2003: „Våbenofferfundene gennem 150 år - forskning og tolkninger “. I: Jørgensen, L. (ed., et al.): Sejrens triumf. Norden i skyggen af det romerske imperium, s. 84-89, Nationalmuseet, København.

Laur, W. 1987: »Der Schleswig-holsteinische Eisenwald und die Edda«, s. 13-25, Zeitschrift der Gesellschaft für Schleswig-Holsteinische Geschichte.

Mager, F. 1930: Entwicklungsgeschichte der kulturlandschaft des herzogtums Schleswig in historischer zeit, b. 1 \& 2 , Ferdinand Hirt, Breslau.

Madsen, O. 2008: „Forhistorien indtil
700 «. I: Schultz Hansen, H., Henningsen, L.N. \& Porskrog Rasmussen, C. (red.): Sonderjyllands historie 1 - indtil 1815 , s. $11-40$.

Matthiessen, H. 1930: Harvejen. En tusindårig vej fra Viborg til Danevirke, Gyldendal, København.

Meier, D. 2000: „Senderjylland fra natur- til kulturlandskab «. I: Ethelberg, P. (et al.): Det sønderjyske landbrugshistorie - Sten-og bronzealder, b. 1, s. 1162, Haderslev Museum og Historisk Samfund for Sønderjylland, Haderslev.

Møller, H.G. 1870: Den ældre Edda, http:/ / www.heimskringla.no/ dansk/edda/index.php.

Neumann, H. 1982: Olgerdiget - et bidrag til Danmarks tidligste historie, Skrifter fra Museumsrådet for Sønderjyllands Amt, vol. 1.

Olrik, J. 1900-01: Krøniker fra Valdemarstiden, Kobenhavn.

Olsen, R.A. 1999: "Middelalderlige befæstningsværker i Danmark«. I: Jantzen C. (red., et al): Voldsteder $i$ Danmark. En vejviser. Jylland II, s. 11-47, Skippershoved.

Pilgaard, M. 2008: Farrisskoven - Myte eller realitet? En kulturhistorisk analyse af betydningen of territorialitet med udgangspunkt i det arkæologiske materiale, Speciale, Afdeling for Forhistorisk Arkæologi, Institut for Antropologi, Arkæologi og Lingvistik, Århus Universitet.

Poulsen, B. 2003: »Middelalderens fødsel - tiden 1000-1340 - samfund og mennesker«. I: Ethelberg, P. (et al.): Det sonderjuske landbrugs historie Jernalder, vikingetid og middelalder, b. 2, s. 375-433, Haderslev Museum og Historisk Samfund for Sønderjylland, Haderslev.

Poulsen, B. 2008: "Hertugdømmets dannelse 700-1544«. I: Schultz Hansen, H., Henningsen, L.N. \& Porskrog Rasmussen, C. (red.): Sønderjyllands historie 1-indtil 1815, s. 41-186.

Ramquist, P. 1991: „Perspektiv på regional variation och samhälle i Nordens folkevandringstid«. I: Fabech, C. \& Ringtved J. (red.): Samfundsorganisation og regional variation. Norden i romersk jernalder og folkevandringstid, s. 
305-319, Jysk Arkæologisk Selskab XXVII.

Ringtved, J. 1986: "Jyske gravfund fra yngre romertid ", s. 95-231, KUML.

Ringtved, J. 1988: "Regionalitet. Et jysk eksempel fra yngre romertid og

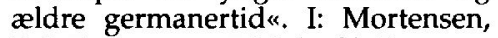
P. \& Rasmussen. B.M. (red.): Fra stamme til stat $i$ Danmark - 1. Jernalderens stammesamfund, s. 37-52, Jysk Arkæologisk Selskabs Skrifter XXII.

Roesdahl, E. 1987: Vikingernes verden. Vikingerne hjemme og ude, Gyldendal.

Sawyer, P. 1988: Da Danmark blev til Danmark - Fra ca. dir 700 til ca. 1050, Politikens og Gyldendals Danmarkshistorie, b. 3, Kabenhavn.

Schou Jørgensen, M. 1988: „Vej, vejstrøg og vejspærring, Jernalderens landfærdsel». I: Mortensen, P. \& Rasmussen, B.M. (red.): Fra stamme til stat $i$ Danmark I. Jernalderens stammesamfund, s. 101-116, Jysk Arkæologisk Selskabs Skrifter XXII, Jysk Arkæoologisk Selskab, Moesgaard.

Schou Jørgensen, M. 2001: »Forhistoriske veje. Nogle problemer og perspektiver med udgangspunkt i dansk materiale «. I: Larsson, L. (red): Kommunikation i tid och rum, s. 3-14, Report series no. 82, Institute of Archaeology, University of Lund, Lund.

Steinsland, G. 2005: Norron religion. $M y-$ ter, riter og samfunn, Pax Forlag A/S, Oslo.

Steuer, H. 1999: "Grenze $-\S 2$. Archäologisches«, s. 5-10, Reallexicon der
Germanischen Altertumskunde, Walter de Gruytter, Berlin, New York.

Sørensen, A.B. 2003: "Middelalderens fødsel - tiden 1000-1340 - huse, gårde og bebyggelser «. I: Ethelberg, P. (et al.): Det sønderjyske landbrugs historieJernalder, vikingetid og middelalder, b. 2, s. 434-457, Haderslev Museum og Historisk Samfund for Sønderjylland, Haderslev.

Tiefenbach, H. 1999: "Grenze. §1. Sprachliches«, s. 3-5, Reallexicon der Germanischen Altertumskunde, Water de Gruytter, Berlin, New York.

Timpe, D. (1989): "Wegeverhältnisse und römische okkupation Germaniens". I: Jankuhn, H., Kimmig, W. \& Ebel, E. (hrsg.): Untersuchungen zu handel und verkehr der vor- und friihgeschichtlichen Zeit in Mittel- og Nordeuropa. Teil V. Der verkehr. Verkehrswege, verkehrsmittel, organisation, Bericht über die kolloqiuen der kommission für die altertumskunde Mittel- und Nordeuropas in den jahren 1980 bis 1983, Göttingen.

Wittendorff, A. 1973: Alvej og Kongevej. Studier $i$ samfardselsforhold og vejenes topografi $i$ det 16. og 17. århundrede, Akademisk Forlag, Kobenhavn.

Wulff Andersen, S. 1993: " $Æ$ Vold «, s. 913, Skalk nr. 4.

Aakjær, S. 1926-43: Kong Valdemars Jordebog, b. 1-3, Samfund til udgivelse af gammel nordisk litteratur, Købehavn.

\section{NOTER}

1. Timpe 1989.

2. Fabech 1993, s. 220.

3. Tiefenbach 1999, s. 3f, og Kratochwil 1986, s. $35 f$.

4. Davies \& Vierck 1974, s. 242f, Neumann 1982, s. 68f, og Stuer 1999, s. $5 f$.

5. Darby 1934, s. 188f, Neumann 1982, s. $68 \mathrm{f}$, og Fabech 1993, s. $220 \mathrm{f}$.

6. Fabech 1993, s. 202 og s. 218.

7. Hoff 1997, s. $248 f$.

8. Jöns 1992/93.

9. Darby 1934, s. 190f, og Kehne 1999, s. $12 \mathrm{f}$.

10. Hardt 2001, s. 282.

11. Jørgensen 1994, s. 57f.

12. Steuer 1999 , s. 6.

13. Harrisson 2001, s. 84f.

14. Steinsland 2005, s. $362 \mathrm{f}$.

15. Poulsen 2008, s. 45.

16. Møller 1870 og Laur 1987, s. $15 f$.

17. Fabech 1993, s. 222 f og Ramqvist 1991, s. 311.

18. Et klassisk værk om udviklingen 
af det slesvigske kulturlandskab, herunder udnyttelse af skovene, fra forhistorisk tid op til nutiden, er (Mager 1930).

19. Hermansen 1947, s. 164.

20. Poulsen 2003, s. 377f, og Hermansen 1947, s. 161.

21. Domeier \& Haack 1963.

22. Pilgaard 2008, s. 7-26.

23. Skoven er kendt under flere navne. Det danske navn er »Jernved" (næunt år 1231) og også "Jarnwith" (nævnt år 1259), og $\mathrm{i}$ den nordiske mytologi bruges navnet Iarnwith. På tysk hedder skoven Isarnho eller Isernho og i nyere tid Dänischen Wohld.

24. Adam af Bremen ca. 1075, s. 242, s. 79, og note 10 s. 79.

25. Olrik 1900-01, s. 134.

26. Aakjær 1926-1943, b. 1. s. 97f.

27. Laur 1987, s. 14, og Benesch 1999, s. $12 \mathrm{f}$.

28. Jørgensen 2003, s. 202.

29. Andresen (et al.) 2008, s. 4.

30. Neumann 1982, s. 64, og Jorgensen 2003, s. 203.

31. Becker-Christensen 1981, s. $82 \mathrm{f}$ og $101 f$.

32. Matthiessen 1930, s. $11 \mathrm{f}$.

33. Wittendorf 1973 , s. $35 \mathrm{f}$.

34. Schou Jorgensen 1988, s. 106, og Schou Jorgensen 2001.

35. Neumann 1982, s. 31f, Jørgensen 2003, s. 203f, og Wulff Andersen 1993, s. 10 f.

36. Neumann 1982, s. $15 f$ og $57 f$, og Christensen 2006.

37. Neumann 1982, s. 58f, Christensen 2006, s. 9, og Ethelberg 2007, s. $147 \mathrm{f}$.

38. Ethelberg 2007, s. 148, og Wulff Andersen 1993, s. 11.

39. Neumann 1982, s. $62 \mathrm{f}$, og Wulff Andersen 1993, s. 13.

40. Christensen 2006, s. 7.

41. Ethelberg 2003, s. 165f.

42. Hverken mod syd eller nord er Over Jerstal-kredsens afgrænsning fastlagt nøjagtig. Grænserne er flydende afhængig af hvilken materiale- eller anlægstype, der vælges at tage udgangspunkt i. Udbredelsen af de ældste våbengrave, ældste jordfæstegrave, enkeltbelig- gende fyrstegrave med romersk import, jordfæestegrave uden våben og huse uden tætstillede stolper $i$ staldene findes dog entydigt kun i områderne nord og vest for Olgerdiget (Ethelberg 2003, s. $196 \mathrm{f}$ ).

43. Neumann 1982, s. $72 \mathrm{f}$ og 84f, Ethelberg 2003, s. $165 f$ og 196f, og Madsen 2008 , s. 27.

44. Ringtved 1988, s. 48, og Ethelberg 2003 , s. $274 \mathrm{f}$.

45. Neumann 1982, s. $65 \mathrm{f}$.

46. Pilgaard 2008, s. 65f, og Andresen (et al.) 2008, s. 4 .

47. Neumann 1982, s. $72 \mathrm{f}$ og 85 , kort 36.b., Ringtved 1986 og 1988, s. 50, note 1, og Ethelberg 2003, s. 222f, 254f, 279 f og 290.

48. Ethelberg 2003, s. $286 f$ og $293 \mathrm{f}$.

49. Ethelberg 2007. Udbredelsen af hustypen kan have relation til Anglerrigets ekspansion, men også skyldes omlægninger i den agrare produktion fra $\mathrm{ca}$. år $200 \mathrm{og}$ /eller været resultatet af kontakt mellem Anglerriget og de jyske naboer (Ethelberg 2003, s. 228).

50. Ethelberg 2007, s. $151 \mathrm{f}$.

51. Lund Hansen 2003, s. $87 \mathrm{f}$.

52. Jørgensen 2003, s. $197 \mathrm{f}$.

53. Ethelberg 2003, s. 317, Dobat 2003 og Dobat 2006.

54. Ethelberg 2003, s. 271f. Den fundtomme periode frem til det 8 . århundrede kan måske ses som udtryk for udvandring, men kan også skyldes helt andre årsager som ændringer i byggeskik, dyrkningsmetoder og gravskik samt i øvrigt dårlige dateringsredskaber og en svær periode at erkende arkæologisk.

55. Se f.eks. Jensen 2003 og 2004.

56. Jørgensen 2003, s. $197 \mathrm{f}$.

57. Christoffersen \& Porsmose 1996, s. $158 \mathrm{f}$

58. Roesdahl 1987, s. 153 , Helmuth Andersen 2004, s. 25f, 31f og 37f, og Kramer \& Hardt 2007, s. $89 f$.

59. Roesdahl 1987, s. 153.

60. Jensen 2004, s. $244 f$.

61. Kramer \& Hardt 2007, s. 90 f.

62. Olsen 1999, s. 11f, og Helmuth Andersen 1992. 
63. Jantzen \& Madsen 1999, s. 135 f.

64. Becker-Christensen 1981, s. 216f, og Anspach 2007, s. 139f.

65. Jørgensen 1994, s. 56f, og Sawyer, 1988, s. 22 og 231.

66. Sawyer 1988, s. 109.

67. Poulsen 2008, s. $76 f$.

68. Poulsen 2008, s. 59 f.

69. Poulsen 2003, s. $403 \mathrm{f}$.

70. Poulsen 2003, s. $381 \mathrm{f}$.
71. Fritzbøger 2004, s. 62 og 376.

72. Fabech 1993 og Fabech og Ringtved 1995, s. 11f.

73. Hoff 1997.

74. Ethelberg 2003, s. 371f, og Sørensen 2003, s. 457.

75. Pilgaard 2008, s. 8f.

76. Pilgaard 2008, s. $72 \mathrm{f}$.

77. Grau Møller og Porsmose 1997, s. $44 \mathrm{f}$. 